\title{
The Evaluation of the Producers' View towards a Local Agricultural Food Product for Marketing; Isot Pepper of Sanllurfa-GAP, Turkey
}

\author{
Mustafa H. Aydogdu ${ }^{1 *}$, A. Ferit Atasoy ${ }^{2}$, M. Emre Eren ${ }^{3}$, Nusret Mutlu ${ }^{4}$, Aziz \\ Korkmaz $^{5}$ \\ ${ }^{1^{*}}$ (Agricultural Economics Department, Agricultural Faculty, Harran University, Turkey) \\ 2,5 (Food Engineering Department, Agricultural Faculty, Harran University, Turkey) \\ ${ }^{3}$ (Technical Sciences Vocational School, Harran University, Turkey) \\ ${ }^{4}$ (Ministry of Development, GAP Regional Development Administration, Turkey)
}

\begin{abstract}
It is aimed to evaluate producers' expectations, concerns and views towards to a local agricultural product, known as isot pepper, in GAP Region-Sanlurfa of Turkey by means of problems of this sector by this study. The data come from 125 producers' surveys which were selected by simple random sampling method that were mainly from small scale entrepreneurships and interviewed face to face by the questionnaire. Likert scales and SPSS were used for the analyses. The results indicate that taste is the most important factor, more than half of the selling was done directly to the consumers within the province, mostly in black color with an open bag way. The price, branding and marketing were the main problems in the sector. The producers were not satisfied with the current prices and there were differences between the current and expected prices by $8.4 \%$ for the quality isot pepper and $22.7 \%$ for the normal one. These differences can be closed easily by differentiated product presentation, advertising and branding This study is the one of first of its kind for Şanlurfa isot pepper in terms of the producer side.
\end{abstract}

Keywords: GAP-Sanliurfa-Turkey, isot pepper, local agricultural products, marketing, producers' views and expectations

\section{Introduction}

It is essential to make production for increasing the population's food and consumption needs to be met. The amount of goods and benefits can increase with the production and by this way the consumer demands could be met. A product can be located in the market as long as it meets the consumers' needs. It is important to be in sustainable production at agriculture for the benefit of both side, the consumer and the producer. Therefore, consumers' demands should be known and the production must be shaped accordingly these demands. The demands based on attitudes, expectations, satisfactions and views which are important indicators in agriculture [1 to 6] and these indicators form willingness to pay [7,8] and it is an important tool for formation of the appropriate price [9 to 11]. On the other hand, the producer is required to achieve satisfactory profit out of this production. Here are the forefront of marketing activities that is showing a continuation of production feature and it is directed to the production [12].

Şanlıurfa has significant potential in terms of agricultural production areas, due to having the fertile plains, such as Harran plain and being in the GAP (The Southeastern Anatolia Project) Region [13]. Diversification is an important subject for agricultural productions in terms of being alternative crop for better income for the producers. Red pepper cultivation is more prone to being an alternative product in agricultural production. Almost half of the fresh red pepper production in Turkey are produced in Şanlıurfa with 78,294 tons of annual average production [14, 15]. The isot pepper is produced as a spice either by fabrication or traditionally from fresh red pepper under the sun with some special natural treatments, either in red or black colors in Şanlıurfa. In this way, both the lifetime and economic value of the fresh red pepper is increased. If the fresh red pepper may consider as basic product then the isot pepper might be considered as potential or enriched product in terms of marketing. The potential product could be defined as to satisfy consumers' needs by addition some features or differentiation of the product [16] by processing. The color differences mainly arise from treatment styles under the sun with plastic bags and generally it is serving for sale to the costumers in open bags. On the other hand, packaging is important for the consumers, too. Besides, isot pepper is being a spice for foods and also it is a very useful product to health, too. In other words, red pepper is a high value product both in economics and vitamins aspects and it has a quite wide range of usage areas [17]. Many studies have shown that capsaicin (red pepper) may be useful as a nutraceutical, ameliorating metabolic profile and cardiovascular function [18]. Some studies in recent years showed that due to the high concentration of pigment (carotenoids) in red pepper and the vitamins (C, A, E vitamins) minimize cardiovascular diseases and also the risk and 
incidence of certain cancers [19 to 21]. In addition, it has an positive effect on the regulation of blood sugar (hypoglycemic) [22] and may have an inhibitory effect on some neurological diseases, too [23]. It can also prevent unwanted oxidation reactions in the body $[24,25]$ and has been found to play a role in preventing Type 2 diabetes [26]. There are significant effective amount of the carotenoid antioxidants available in isot pepper which is made from fresh red peppers are said to have a positive impact on human health [27].

There are 15 enterprises engaged in manufacturing fabricated isot pepper, 3 enterprises are produced with traditional methods and the number of family businesses engaged in traditional production is around 550 in Şanlıurfa [15]. The total annual production is more than 3,500 tons in Şanlıurfa [15]. On the other hand, the products with regional features are used as a tool for development. In this way, both small family businesses are obtaining more profit and it is also increasing the value added of these products by the processing. Sanliurfa isot pepper is a product with the local property, because of many reasons but it was not obtained the expected added value and branding yet [28].

The scientific studies are needed to affect positively for the better image and the profile of Şanliurfa isot pepper in the market. Because, traditional isot pepper production is preferred by the consumers. It has a market value but it is not at desired level, too. These studies could also be used to ensure the sustainability of local enterprises, producers, protection of local values and as a tool for regional development. It is aimed to determine the problems of isot pepper sector and to define the expectations of the producers in terms of marketing with this study. This study is the one of the first of its type in Şanlıurfa for isot pepper.

\section{Materials and Methods}

The main materials of this study was obtained from Şanllurfa isot pepper producers which were selected by simple random sampling method and interviewed face to face by a questionnaire. Within this scope 125 surveys were conducted with the participants who produce isot pepper which were mainly from the small scale family enterprises. The obtained data was transferred to Excel with a coding plan and it is used for the analysis. It is aimed to get detail analysis to explore the situation of isot pepper in the markets by means of producers side and define their expectations for sustainable production.

Likert attitude scale was used in this study that is developed by R. Likert (1930) in USA and widely used by the researchers to define attitudes, behaviors and expectations of a certain group about the researched topic. There are two situations in Likert scale; the wanted and the unwanted case. In the questionnaires, various questions were asked to determine attitudes and expectations of the producers' towards to isot pepper in terms of marketing. The principle is that producers assign their judgment in the researched topics that is isot, dried red pepper, ranging from "strongly agree" to "strongly disagree" and focusing on these judgments. The judgment statements should have a single meaning and definite outcomes in order not to confuse the participants. The accepted confidence level in Likert scale is $85 \%$ in general [29]. Besides, the measurements were made using SPSS in order to define the reliability of statistics and intra class correlation coefficient for statistical significance.

\subsection{Reliability Statistics}

Cronbach's Alpha is used for the evaluation of Likert type questions and it measures internal consistency, which provides information about the reliability of a multi-item scale. If the Cronbach's Alpha coefficient is high, the scale of substances said to be consistent with each other [30]. Values exceeding 0.6 indicate internal consistent scales, in other words, all items incorporated in the scale measure the same underlying construct [31 to 33]. The Cronbach's Alpha coefficient from data set found as 0.81 and interclass correlation coefficient significance of $F$ test with true value 0 was measured as $p<0.01$ and given in Table 1 that indicates this research is reliable.

\section{Results and Discussion}

The descriptive statistics are given Table 2, where $50.4 \%$ of respondents were female and $49.6 \%$ male and $59.2 \%$ of them graduated from primary school, $23.2 \%$ of them from high school, and $17.6 \%$ of them graduated from higher education schools. The information about the sales of the producers are located in Table 3. According to the results more than half of the producers are selling isot pepper directly to the consumers mostly with the open bags and black in color. This is expected due to being of the isot pepper a traditional local product. Direct selling is a case in favor of both producers and consumers alike. Firstly, both sides saves the certain amount of money that is paid for intermediation activities. Secondly, there is an direct communications between both side that results to saving of time to understand demands and supply sides each other's based on expectations [34].

Producers were asked a question with options in order to identify the problems of isot pepper sector. They were also asked to rank in order of importance of these options by giving them to scores. By this way, analysis of the producers' overview to the problems in the sector was determined. According to the results, the 
most important problem was price that is the basic function of income. The least important one was the weight and the amount of it due to selling in open bag that is the consumers have the freedom to take any amount they want. The distribution of the factors that ranked by the producers are given in Table 4 .

The price is the most important factors in the sector according to the results that is an expected result. In fact, price is a flexible marketing tool and a value that is determined by the producers to their product [16]. In other words, price is revenue for producers and expenditure for the consumers. In this sense, price is a function of income. Supply is a result of agricultural production activities based on some costs. The supply of agricultural products are shaped depending on the production conditions and the given price by the consumers for goods. Products in order to be seen in the consumer market depend on finding buyers to across the charges that is spent by the producers [12] in order to make production. The price should be satisfactory to the producers in order to be able to supply of the goods and also should be reasonable for the consumers to buy. The production technique is also one of the factors that is constituting the supply. Isot pepper has local special production process that makes distinctiveness among the other types. Therefore production place also has importance and ranked at second important factor by the producers. A great deal of research focuses on how consumers shop, but the rationale behind their chosen behaviors remains somewhat underserved [35]. Selling place (shops) play a major role in purchase decisions. The consumers want to be ensure about selling place that is simply the consumer wants to leave the store happy and satisfied [36]. Consumers, in other word customers, are the most important people for any organization. They are the resource upon which the success of the business depends. Consumer satisfaction is at the heart of the selling process. One estimate is that it costs five times as much to attract new customers as it does to keep an existing one. The relationship between the customer and the organization is, therefore, an important one [37] because of without the consumers the organization would not exist. Branding and the brand value are considered to be the net present value of the estimated future cash flows attributable to the brand [38].

The producers are able to sell isot pepper directly to the consumers due to being local product and more than half of selling is done by this way. So, the producers can easily get feedback from the consumers about their product. Producers were asked a question with options in order to identify the consumers preferences during shopping, like attention for buying or the reasons for selection. They were also asked to rank in order of importance of these options by giving them scores. In other words, it has been requested to make ranking from the highest to the smallest numbers according to the their preferences. By this way, analysis of the consumers' preferences to the buying was determined. According to the results, the most important preferences was the taste of the isot pepper that is the sense, perception to distinguish the flavor. A person can perceive literally hundreds of different tastes as combinations sensations [39]. Not only does food nourish the body, it provides nourishment for the soul. One reason that taste and smell sensations are important is that they prepare human bodies for digesting food. There is another reason why taste and smell are crucial to health due to these senses provide information about the food [40]. The least one was the price that may sounds a contradiction according to the results of the producers but it is self consistent and significant. The distribution of the factors that ranked by the producers are given in Table 5 .

The most important details in two consecutive tables were given above was the price and these results were significant. The producers are not finding the current sales price as enough satisfying their expectations and expenditures. In other words, they consider that current sales price was low. This result was also confirmed by the consumers that they gave least attention to the price during the buying of isot pepper. It means that either price was low or not important as compared with the other factors for buying preferences to the consumers. This result was also concluded that the survey with the producers were consistent itself. Accordingly, the producers were asked that what should be the price of quality and the normal isot pepper in the market. The responses received are given in Table 6.

In fact, the quality isot pepper selling price was around $30 \mathrm{TL}$ (Turkish Lira) and the normal ones were around $15 \mathrm{TL}$ at surveyed time. The differences between the current and expected prices are low that is $8.4 \%$ for the quality one and $22.7 \%$ for the normal ones. These differences can be closed with a simple marketing techniques such as promotion, advertising and more information about its benefit for health at broadcasting. The increase of economic and social welfare affects the consumer behaviors. A study conducted in Tokat province of Turkey is showed that more than half of the consumers are concerned about food security in terms of health consideration. It is also identified that $75.8 \%$ of the consumers tend to overpay for safe food. It has been concluded that the most of the information about food safety acquired from radio-television programs and TV advertising in which most influenced on the decision of purchase [41].

Producers were asked a question with options in order to identify the market problems of isot pepper sector. They were also asked to rank in order to importance of these options by giving them scores that is starting from the heights value to the lowest ones. By this way, the market problems of the sector was determined. According to the results, the most important problem was marketing. Because of isot pepper is being a local product, there is a marketing problem in general. In fact, finance, marketing and access to the 
domestic markets are the major problems for small scale entrepreneurships. The small scale industries play a significant role in the economic development of the country by stimulating entrepreneurial skills, generating employment and contributing to export [42]. The least important one was the food safety, diseases and pests. This result is contradictory to the consumers. Since its produced by locally that is mainly by small family entrepreneurship, the producers believe that there is no risk of diseases and pests, so food safety is ensured. On the other hand, food safety is an important indicator for the costumers. In this regard, food safety concept has the most fundamental differences between the producers and consumers' point of view. The distribution of the factors that ranked by the producers are given in Table 7 and these results are significant.

Likert type of questions were used in order to determine the perception and attitude of the producers towards to the isot pepper by given factors. Participation factors were measured on the producers. Accordingly, the taste of isot pepper has the highest participation, where the lowest involvement was the place of sold. This is another contradiction between the producers and the consumers. The selling place is important for the customers in terms of easily access to goods for selection, visibility, accessibility and trust. However, selling place has not been enough solely, the sellers are also as important as in marketing. The producers believe that it is not important for quality products. In fact, it might be true for only local markets are taken into considerations, but not true for domestic and international markets, too. Given answers were located in Table 8.

\section{Tables}

Table 1. Intraclass Correlation Coefficient

\begin{tabular}{|l|c|c|c|c|c|c|c|}
\hline & $\begin{array}{c}\text { Intraclass } \\
\text { Correlation }\end{array}$ & \multicolumn{2}{|c|}{ 95\% Confidence Interval } & \multicolumn{4}{|c|}{ F Test with True Value 0 } \\
\hline & & Lower Bound & Upper Bound & Value & df1 & df2 & Sig \\
\hline Single Measures & 0,094 & 0,071 & 0,125 & 5,249 & 124,0 & 4960 & $0,000^{*}$ \\
\hline Average Measures & 0,809 & 0,758 & 0,854 & 5,249 & 124,0 & 4960 & $0,000^{*}$ \\
\hline
\end{tabular}

*indicates statistically importance of $1 \%$

Table 2. Descriptive Statistics

\begin{tabular}{|l|c|c|c|}
\hline & The Producer & Mean & Std. Deviation \\
\hline Gender & If male 1, female 2 & 1,50 & 0,502 \\
\hline Education level & $\begin{array}{c}\text { If graduated from primary school 1, from high school 2, from higher } \\
\text { education 3 }\end{array}$ & 1,58 & 0,774 \\
\hline Years In Sector & Years in production of isot pepper sector & 13,50 & 11,809 \\
\hline Production amount & The average yearly total production amount (kg/year) & 3007,14 & 11906,682 \\
\hline Selling amount & The average yearly selling amount (kg/ year) & 2990,86 & 11908,055 \\
\hline
\end{tabular}

Table 3. Some information about the producer sales

\begin{tabular}{|l|c|l|c|}
\hline Sales are made to whom? & $\mathbf{\%}$ & What is the preferred color in Sales? & \% \\
\hline Wholesalers & 14.4 & Black & 44.8 \\
\hline Retailers & 4.8 & Red & 20.0 \\
\hline Markets & 3.2 & Both of them & 35.2 \\
\hline Directly to consumer & 53.6 & Where are sales made? & \% \\
\hline Some of these & 24 & Sales within the province & 70.4 \\
\hline How are sales performed? & $\mathbf{\%}$ & Intra-regional sales & 12.0 \\
\hline With the open bag & 71.2 & Within the country & 11.2 \\
\hline With the packing box & 5.4 & Some of these & 6.4 \\
\hline Both of them & 23.4 & & \\
\hline
\end{tabular}

Table 4. The problem of isot pepper sectors

\begin{tabular}{|l|c|}
\hline Factors & Percentage of importance \\
\hline Price & 78.97 \\
\hline Food safety certificate & 72.57 \\
\hline Branding and brand values of trust given & 73.60 \\
\hline Place of production (Produced province and Region) & 78.40 \\
\hline Packaging and its appearance & 59.52 \\
\hline Weight and the amount of it & 56.34 \\
\hline Selling place/shop & 76.91 \\
\hline
\end{tabular}

Table 5. The consumer preferences during buying of the isot pepper

\begin{tabular}{|l|c|}
\hline Factors (Of the isot pepper) & Percentage of importance \\
\hline The color & 85.26 \\
\hline The smell & 80.57 \\
\hline The appearance & 73.94 \\
\hline The hygiene conditions & 84.12 \\
\hline The taste & 89.83 \\
\hline The bitterness & 81.37 \\
\hline The price & 70.06 \\
\hline
\end{tabular}


The Evaluation of the Producers' View towards a Local Agricultural Food Product for Marketing..

Table 6. The isot pepper prices should be based on producers (TL=Turkish Lira)

\begin{tabular}{|l|c|c|c|}
\hline Isot pepper quality type & Minimum price & Maximum price & Average price \\
\hline The quality isot pepper & $25 \mathrm{TL}$ & $70 \mathrm{TL}$ & $32.52 \mathrm{TL}$ \\
\hline Normal isot pepper & $10 \mathrm{TL}$ & $50 \mathrm{TL}$ & $18.41 \mathrm{TL}$ \\
\hline
\end{tabular}

Table 7. The market problems of the isot pepper according to the producers

\begin{tabular}{|l|c|}
\hline Factors (Of the isot pepper sector) & Percentage of importance \\
\hline Market deficiency & 68.8 \\
\hline Marketing & 80.9 \\
\hline Inability to branding & 67.4 \\
\hline Promotion & 79.3 \\
\hline Counterfeit goods & 67.2 \\
\hline Market prices & 71.2 \\
\hline Lack of producers' associations & 71.3 \\
\hline Food safety, diseases and pests & 65.5 \\
\hline
\end{tabular}

Table 8. The producers' participations to the factors

\begin{tabular}{|l|c|}
\hline Factors (Of the isot pepper) & Percentage of importance \\
\hline Color and smell are important & 88.48 \\
\hline Taste is very important & 93.12 \\
\hline Isot pepper is bitter and bitterness is important & 88.16 \\
\hline Production province and region is important & 87.68 \\
\hline Food security is important during the processing of it & 84.48 \\
\hline The brand is important for marketing & 80.48 \\
\hline Packaging is effective in buying for the consumers & 71.68 \\
\hline Selling place is important to purchase & 69.12 \\
\hline There are problems in the marketing sector & 80.48 \\
\hline Isot pepper could not become a brand for marketing & 75.20 \\
\hline
\end{tabular}

\section{Conclusion}

Diversification is a need for sustainable agricultural production and necessary for better income for the farmers. Featured local agricultural products are important for regional development. Isot pepper is a diversification of fresh red pepper, an alternative product and has market value. There is a branding and marketing problems of isot pepper, due to being a local product and mainly produced by the small entrepreneurships. The current price was not found satisfactory by the producers to meet their expectations. The differences between the current and expected prices are $8.4 \%$ for the quality isot pepper and $22.7 \%$ for the normal isot pepper. These differences can be closed easily by differentiated product presentation, advertising, food safety certificate and branding. In fact the consumers are able to pay these differences, because price was found has less priority for buying isot pepper at consumers' surveys. The branding and marketing problems may have been overcome by the establishment of a producers' associations. In this way, the production would be achieved a more standard way with a food safety certificate and fulfill the needs of the consumers that makes contribution to branding. The majority of consumers are finding traditional food products as moderately safe [43]. The Counterfeit goods, the hygiene conditions, food safety, diseases and pests are important issues for both side, the consumers and the producers. The food safety certificate will eliminate the concerns of the consumers by this way too. The branding develops consumers' loyalty and satisfaction, too. The marketing and branding are the backbone of selling that helps to provide more income and sustainability for the producers. Establishment of supply and demand balance are important for the benefit of the both sides. The outcome of this research may be used to the establishment of this balance. This study is the one of first of its kind for Şanlıurfa isot pepper in terms of the producer side.

\section{Acknowledgements}

This study was supported by Republic of Turkey, Ministry of Development, GAP Regional Development Administration by the project name of GAPISOT.

\section{References}

[1] M.H. Aydogdu, Evaluation of the managers' views to water user associations in GAP-Harran Plain, Turkey. Basic Research Journal of Agricultural Science and Review. 4(2), 2015, 064-070. ISSN 2315-6880

[2] M.H. Aydogdu and M. Aydogdu, Attitudes of the Water Authority to Water User Associations and the Management; GAP Region, Sanliurfa-Turkey. International Journal of Current Science, 15, 2015, 43-48. ISSN 2250-1770

[3] M.H. Aydogdu, B. Karli, K. Yenigun and M. Aydogdu, The farmers' views and expectations to the Water User Associations; GAP-Harran plain sampling, Turkey. Global Advanced Research Journal of Agricultural Science 4(1): 2015a, 033-041. ISSN: 2315-5094

[4] M.H. Aydogdu, B. Karli and M. Aydogdu, The Attitudes Of Stakeholders To Water User Associations And Water Management: GAPHarran Plain Sampling. The Journal of Academic Social Science, ASOS Journal. 3(14), 2015B, 93-103. Doi Number: http://dx.doi.org/10.16992/ASOS.710 
[5] M.H. Aydogdu, B. Karli and M. Aydogdu, Evaluation of attitude of stakeholders for irrigation water management: A case study of Harran Plain, Turkey. Journal of Environmental \& Agricultural Sciences 4, 2015c, 42-47.

[6] M. H. Aydogdu, K. Yenigun and M. Aydogdu, Factors affecting farmers' satisfaction from water user associations in the Harran Plain-GAP Region, Turkey. Journal of Agricultural Science and Techonology. 17(Supplementary issue), 2015d, 1669-1684.

[7] M.H. Aydogdu, B. Karl, K. Yenigün and M. Aydogdu, M. Evaluation of Farmers' Willingness to Pay for Water under Shortages: a case study of Harran Plain, Turkey. Journal of Environmental \& Agricultural Sciences 7, 2016a, 23-28.

[8] M.H. Aydogdu and K. Yenigun, Willingness To Pay For Sustainable Water Usage In Harran Plain-GAP Region, Turkey. Applied Ecology And Environmental Research 14(3), 2016, 147-160. DOI:http://dx.doi.org/10.15666/aeer/1403_147160

[9] M.H. Aydogdu, B. Karlı, K. Yenigün, A.R. Manci and M. Aydogdu, Pricing trends in agricultural irrigation; attitudes and perceptions of farmers to pricing; GAP Harran Plain irrigations, Şanliurfa. The Journal of Academic Social Science Studies, 29, 2014a, 165-188. http://dx.doi.org/10.9761/JASSS2529

[10] M.H. Aydogdu, B. Karli and M. Aydogdu, The Overviews Of Water User Association Presidents To Irrigation Water Pricing And Management: The GAP-Harran Plain Irrigations Sampling. International Journal of Social Science, JASSS, 31, $2015 \mathrm{e}, 167-177$. Doi:http://dx.doi.org/10.9761/JASSS2694.

[11] M.H. Aydogdu, A.R. MancI and M. Aydogdu, M. The Changes In Agricultural Water Management; Water User Associations, Pricing And Privatization Process. Electronic Journal of Social Sciences, 14(52), 2015f, 146-160. DOI: http://dx.doi.org/10.17755/esosder.82927.

[12] T. Günes, Agricultural Marketing, Ankara University, Faculty of Agriculture Publications No:1467, 1996, Ankara.

[13] M.H. Aydogdu, Willingness To Pay For Sustainable Water Usage In Harran Plain-Gap Region, Turkey. Applied Ecology And Environmental Research, 14(3), 2016, 147-160. DOI:http://dx.doi.org/10.15666/aeer/1403_147160

[14] TUIK, Fresh Red Pepper produced data and production statistics, Türkiye Istatistik Kurumu,2012 Ankara. (In Turkish).

[15] GTHB, Some data related with pepper produced at Şanlıurfa, Glda, Tarım ve Hayvancllık Bakanlıgı, 2012, Ankara. (In Turkish)

[16] I. Caglar and S. Kilic, Marketing. (Ankara: Nobel Yayinları, 2005) (In Turkish)

[17] M. Nearing, "5 health benefits of peppers" www.besthealthmag.ca/best-eats/nutrition/5-health-benefits-of peppersslide=6\&re (Accessed 17 October 2015).

[18] S.C. Tremarin, K.R. Casali, L. Meurer and B.D. Schaan, Capsaicin-induced metabolic and cardiovascular autonomic improvement in an animal model of the metabolic syndrome. British Journal of Nutrition, 111, 2014, 207-214. doi:10.1017/S0007114513002493.

[19] S.T. Mayne, Antioxidant Nutrients and Chronic Disease: use of Biomarkers of Exposure and Oxidative Stress Status in Epidemiologic Research. The Journal of Nutrition, 133, 2003, 933-940.

[20] E.M. Yahia and J. DE. J. Ornelas-Paz, Chemistry, Stability and Biological Actions of Carotenoids. In De La Osa, L. A., Alvarez-Parilla, E., Gonzalez-Aguilar, G. A., (Eds.), Fruit and Vegetable Phytochemicals: Chemistry, Nutritional Value and Stability,(Iowa: Blackwell Publishing, 2010). pp.77-222.

[21] J. W. Finley, A. N. Kong, K. J. Hintze, E. H. Jeffery, L. L. Ji And X.G.Lei, Antioxidant in Foods: State of the Science Important to the Food Industry. Journal of Agricultural and Food Chemistry, 59, 2011, 6837-6846.

[22] M.R. Loizzo, A. Pugliesse, M. Bonesi, D. De Luca, N. O’brien, F. Menichini and R. Tundis, Influence of Drying And Cooking Process on The Phytochemical Content, Antioxidant and Hypoglycaemic Properties af Two Bell Capsicum Annum L. Cultivars. Food and Chemical Toxicology, 53, 2013, 392-401.

[23] M.W. Davey, M. Montagu, D. Inze, M. Sanmartin, A. Kanellis, and N. Smirnoff, Plant L-ascorbic Acid: Chemistry, Function, Metabolism, Bioavailability and Effects af Processing. Journal of the Science of Food and Agriculture, 80, 2000, 825-860.

[24] G. Obob, R.L.Puntel and J.B.T. Rocha, Hot Pepper (Capsicum annuum, Tepin and Capsicum Chinese, Habanero) Prevents Fe2+-Induced Lipid Peroxidation in Brain - in vitro, Food Chemistry, 102, 2007, 178-185.

[25] H. Yang, D.J. Jang And J.T. Hwang, Anti-diabetic Effects of Korean Red Pepper via AMPK and PPAR-c activation in C2C12 Myotubes. Journal of Functional Foods, 4, 2012, 552-558.

[26] L.G. Ranilla, Y.I. Kwon, E. Apostolidis and K. Shetty, Phenolic Compounds, Antioxidant Activity and in vitro Inhibitory Potential Against Key Enzymes Relevant for Hyperglycemia and Hypertension of Commonly Used Medicinal Plants, Herbs and Spices in Latin America. Bioresource Technology, 101, 2010, 4676-4689.

[27] A. Korkmaz, M.H. Aydogdu, N. Mutlu and A.F. Atasoy. Determination of Some Physicochemical and Color Properties of Traditional and Industrial İsot. Harran Journal of Agricultural and Food Sciences, Article In Press. 2016.

[28] M.H. Aydogdu, A.F. Atasoy, M.E. Eren, and N. Mutlu, The Consumers' Behaviors Towards To a Regional Agricultural Product in Turkey. IOSR Journal of Agriculture and Veterinary Science (IOSR-JAVS). 9(5), 2016b, 25-30. DOI: 10.9790/2380-0905022530

[29] M.H. Aydogdu, A.R. Manci and M. Aydogdu, The Overviews And Perceptions Of Faculty Of Agriculture Students Of Harran University To Agricultural Policies Of Turkey. Turkish Studies, 9(11), 2014b, 63-77. Doi Number: http://dx.doi.org/10.7827/TurkishStudies.7348

[30] R. Alpar, Applied Multivariate Statistical Methods, (Ankara: Detay Yayıncıllk, 2013)

[31] I. Vermeir and W. Verbeke, Sustainable Food Consumption: Exploring the Consumer "Attitude-Behavioral Intention" Gap. Journal of Agricultural Environmental Ethics, 19, 2006, 169-194. Doi:10.1007/s10806-005-5485-3

[32] E. Özdamar, Data Analysis and Statistical Package Programs I. (Eskişehir: Kaan Kitapevi, 1999) (In Turkish).

[33] E. Tavşancıl, Measurement of attitudes and SPSS Data Analysis. (Ankara: Nobel Yayınları, 2002) (In Turkish)

[34] O.B. Tek. Principles of marketing. 8th Edition.(Istanbul: Beta Basım Yayım, 1999) (In Turkish)

[35] A.K. Paul and S.K. Hogan, Understanding consumer shopping behavior. Deloitte University Press, 2015, http://dupress.com/articles/understanding-consumer-behavior-shopping-trends/ (Accessed at: August, 06, 2016)

[36] C. Hopwood, Why direct-to-consumer is becoming an important retail channel, 2016 https://www.visioncritical.com/direct-to-consumermarketing-channel/(Accessed at: August, 06, 2016)

[37] Anonymous, Why customers are important, Marketing Theory, 2016a. http://businesscasestudies.co.uk/business-theory/marketing/whycustomers-are-important.html\# axzz4GUqRw0xB (Accessed at: August, 07, 2016)

[38] Anonymous, Brand Value, 2016b. http://brandirectory.com/glossary/definition/brand_value (Accessed at: August, 07, 2016)

[39] A.C. Guyton, Textbook of Medical Physiology 5 (Philadelphia: W.B. Saunders, 1976) ISBN 0-7216-4393-0

[40] Anonymous, About Taste, The Importance of Taste, 2016c. http://www.msginfo.com/about_taste_imp.asp (Accessed at: August, 08, 2016)

[41] E. Onurlubas. Measurement Of Consumers Knowledge Level On Food Safety: A Case Study In Tokat. Ph.D. Thesis. Gaziosmanpasa University Graduate School of Natural and Applied Sciences Department of Agricultural Economics, 2015.

[42] S.N. Jha. and N.K. Agrawal. A Case Study of the Marketing Problems of Small Scale Industries. Management Convergence 1(1). 2010. www.inflibnet.ac.in/ojs/index.php/MC/article/view/587 (Accessed at: August, 08, 2016)

[43] K. Taşdan, M. Albayrak, B. Gürer, O. O.Özer, K. Albayrak, H.T. Güldal, Consumer Perceptions of Food Safety in the traditional food: Ankara Example. 2014. http://yucita.org/uploads/yayinlar/diger/makale/Geleneksel_Gdalarda_Tuketicilerin_Gda_ Guvenlii_Algs.pdf(Accessed at: August, 08, 2016) 